\title{
Esterification of cellulose isolated from black poplar (Populus nigra L.) sawdust with octanoyl chloride
}

\author{
Samim Yaşar ${ }^{\text {a,* (D) }}$
}

\begin{abstract}
In this study, cellulose was isolated from black poplar (Populus nigra L.) sawdust, which is produced by forest industrial processes in large amounts as lignocellulosic waste. Isolated cellulose was then esterified with different concentrations of octanoyl chloride (36-162 mmol, 2-9 equivalent per anhydroglucose unit in cellulose), and the obtained derivatives were characterized in terms of elemental analysis, percent yield, degree of substitution (DS), and solubility. DS values of cellulose derivatives ranged from 1.13 to 2.71 , while percent yields varied between $56.36 \%$ and $93.23 \%$. Solubility analysis revealed that esterification improved the hydrophobic capacity of cellulose. The findings of the study showed that the produced cellulose derivatives might be appropriate for the production of biodegradable and environmentally degradable plastics, resins, films, and coatings for use in some industrial areas such as in the food and pharmaceutical industries.
\end{abstract}

Keywords: Cellulose, Esterification, Elemental analysis, Degree of substitution, Percent yield, Solubility

\section{Karakavak (Populus nigra L.) talaşından izole edilen selülozun oktanoil klorür ile esterlenmesi}

\begin{abstract}
Özet: Bu çalışmada, orman endüstrisi proseslerinde büyük miktarlarda lignoselülozik atık olarak ortaya çıkan karakavak (Populus nigra L.) talaşından selüloz izole edilmiştir. İzole edilen selüloz daha sonra farklı konsantrasyonlardaki oktanoil klorür (36-162 mmol, selülozdaki anhidroglukoz birimi başına 2-9 ekivalent) ile esterlenmiş ve elde edilen türevler elementel analiz, yüzde verim, sübstitüsyon derecesi (DS) ve çözünürlük ile karakterize edilmiştir. Selüloz türevlerinin DS değerleri 1.13 ile 2.71 arasında değişirken, verim yüzdelerinin \%56.36 ile \%93.23 arasında olduğu görülmüştür. Çözünürlük analizi sonucu, esterleme ile selülozun hidrofobik kapasitesinde gelişme olduğu görülmüştür. Çalışma sonuçları, elde edilen selüloz türevlerinin, gıda ve ilaç endüstrileri gibi bazı alanlarda kullanılabilecek biyolojik olarak parçalanabilir ve çevreye karışabilir plastik, reçine, film ve kaplamaların üretimi için uygun olabileceğini göstermiştir.

Anahtar kelimeler: Selüloz, Esterlenme, Elementel analiz, Sübstitüsyon derecesi, Yüzde verim, Çözünürlük
\end{abstract}

\section{Introduction}

The increase in the awareness of environmental protection has recently decreased the use of fossil resources. However, the development of biodegradable products has increased the tendency towards renewable resources (Lange, 2007; Samarasinghe et al., 2007; Arikan and Bilgen, 2019; Moshood et al., 2021). In this respect, cellulose, which is the highest amount of natural organic molecule in the world, constitutes more than $50 \%$ of the total biomass and is of great interest in the chemical industry (Fengel and Wegener,1984; Sjöström, 1993).

In recent years, the application of environmentally friendly chemical processes has enabled the development of new polymers based on renewable resources that can compete with synthetic polymers, thereby reducing dependence on fossil resources. Around 1.5 billion organic cellulose esters are synthesized annually in the world (Sealey et al., 1996). The physical properties of these esters enable them to be used in many areas, particularly in the fiber and plastic industries (Mark et al., 1985). Furthermore, cellulose esters are regarded as a product of environmentally friendly "green" chemistry and offer the potential to be an alternative to petrochemical plastics (Crepy et al., 2009).

Fatty acid chlorides are mightily reagents to generate cellulose fatty acid esters (Willberg-Keyrilainen and Ropponen, 2019). Cellulose fatty acid esters can easily be converted into plastics and exhibit interesting physical properties (Joly et al., 2005 and 2006; Heredia-Guerrero et al., 2017; Nosal et al., 2021). There are different techniques used for acylation of cellulose with fatty substituents. The most commonly used solvent in the esterification of cellulose is the N,N-dimethylacetamide (DMAc) homogeneous system combined with $\mathrm{LiCl}$. With this homogeneous solvent system, a concentrated cellulose solution can be prepared and nondegraded natural polymers can be produced from this solution using saturated acyl substituents (McCormick et al., 1985).

Black poplar (Populus nigra L.) is distributed in Europe, North Africa, Central and West Asia and is particularly prominent on the riversides (Rathmacher et al., 2010). Turkey has 68000 hectares of black poplar plantations and obtains an
$凶 \quad$ a Isparta Uygulamalı Bilimler Üniversitesi, Orman Fakültesi, Isparta

@ * Corresponding author (İletişim yazarı): samimyasar@isparta.edu.tr

$\checkmark \quad$ Received (Geliş tarihi): 05.06.2021, Accepted (Kabul tarihi): 05.08.2021
Citation (Atıf): Yaşar, S., 2021. Esterification of cellulose isolated from black poplar (Populus nigra L.) sawdust with octanoyl chloride. Turkish Journal of Forestry, 22(3): 306-310 DOI: $10.18182 / \mathrm{tjf} .948411$ 
annual 1.9 million $\mathrm{m}^{3}$ of wood from these plantations (Kahraman et al., 2011). Black poplar wood is a source of raw materials commonly used in the production of furniture, packaging materials, composite panels, matches, fruit crates, and building elements (Gaudet et al., 2008). The extensive use of black poplar in the wood industry generates high amounts of wood sawdust as waste. Poplar sawdust are generally used for pellet and biomass briquette production (Mediavilla et al., 2012; Monedero et al., 2015; Wang et al., 2018; Civitarese et al., 2019). However, poplar sawdust may have potential as a raw material for bioplastics production.

In this study, cellulose was isolated from black poplar wood sawdust and esterified with octanoyl chloride (a longchain fatty acid chloride) in $\mathrm{DMAc} / \mathrm{LiCl}$ homogeneous solvent system to produce cellulose derivatives. For characterization of ester derivatives, elemental analysis, yield percentage, degree of substitution (DS), and solubility were used.

\section{Material and method}

\subsection{Material}

\subsubsection{Plant Material}

Black poplar sawdust was taken from Yuceer Sawmill in Isparta-Turkey in 2019. Sawdust was sieved through 40-100 mesh screens.

\subsubsection{Reagents}

Cyclohexane, N,N-dimethylacetamide (DMAc), LiCl, 4Dimethylaminopyridine (DMAP), octanoyl chloride and dimethylsulfoxide (DMSO) were from Sigma-Aldrich, while ethanol, nitric acid, chloroform, methanol, dimethylformamide (DMF), tetrahydrofuran (THF) and dichloromethane were from Merck.

\subsection{Method}

\subsubsection{Isolation of Cellulose}

Extractives were removed from screened sawdust with extraction using cyclohexane: ethanol $(2: 1, \mathrm{v} / \mathrm{v})$ solution for $6 \mathrm{~h}$ in a soxhlet apparatus. From extracted sawdust, cellulose was isolated using method of Kurschner and Hoffer (1969): $2 \mathrm{~g}$ of the sample were weighted in a reaction flask. After addition of $40 \mathrm{~mL}$ ethanol and $10 \mathrm{~mL}$ nitric acid $\left(\mathrm{HNO}_{3}\right)$, the flask was subjected to boil under reflux for $60 \mathrm{~min}$. After filtration, the insoluble residue was retreated 3 more times again using the previous process. Finally, the prepared cellulose was washed with hot distilled water and oven-dried.

\subsubsection{Dissolution of Cellulose}

For removing the water trapped within the structure, cellulose was subjected to a solvent-exchange: cellulose was first dipped into methanol for $30 \mathrm{~min}$ and then into DMAc for 30 min. A LiCl/DMAc solution was prepared with a concentration of $6.7 \%(\mathrm{w} / \mathrm{v})$ by stirring for $60 \mathrm{~min}$ at $60{ }^{\circ} \mathrm{C}$. The treated cellulose was added to the solution of $6.7 \%$ $\mathrm{LiCl} / \mathrm{DMAc}(\mathrm{w} / \mathrm{v})$ and stirred for $12 \mathrm{~h}$ at $70{ }^{\circ} \mathrm{C}$ until complete dissolution (Joly et al., 2003). The concentration of the stock solution was $20 \mathrm{~g}$ cellulose per liter of LiCl/DMAc.

\subsubsection{Octanoylation of Cellulose}

Cellulose (150 mL of stock solution; $3 \mathrm{~g}, 18 \mathrm{mmol})$ and 4-Dimethylaminopyridine (DMAP) (6.6 g, $162 \mathrm{mmol} ; 3$ equivalents per anhydroglucose unit) were stirred at $80{ }^{\circ} \mathrm{C}$ until complete solubilization, and the octanoyl chloride (36$162 \mathrm{mmol}, 2-9$ equivalent per anhydroglucose unit) was then added. The combination was heated at $80{ }^{\circ} \mathrm{C}$ for $3 \mathrm{~h}$ (Joly et al., 2006; Satge et al., 2004; Vaca-Garcia et al., 1998). Afterwards, the product was precipitated by way of addition of methanol. Obtained solid was purified by a repeated solubilization and precipitation process using chloroform and methanol, respectively, and then dried in air at room temperature (Satge et al., 2002).

\subsubsection{Determination of Carbon Content, DS Value and Yield}

The DS values and the yield percentages were calculated based on the assumption that cellulose was converted to trioctanoylated cellulose. In the case, the DS and the yield percentage would be 3 and $100 \%$, respectively (Figure 1).

Carbon contents $(\%)$ of the samples were determined using a Leco CHNS-932 elemental analysis device. DS values were obtained from carbon contents (\%) according to the equation 1. Yield percentages were calculated from DS values using equation 2 .

$$
C(\%)=\frac{9608.8 * D S+7206.6}{126.2 * D S+162.1}
$$

$$
\text { Yield }(\%)=\frac{\mathrm{DS}+1.2849551}{0.04285040}
$$

\subsubsection{Solubility Analysis}

The solubility of octanoylated celluloses was measured in different organic solvents. Analysis was performed using 5 $\mathrm{g}$ of samples in $100 \mathrm{~mL}$ of dimethylsulfoxide (DMSO), dimethylformamide (DMF), tetrahydrofuran (THF), chloroform $\left(\mathrm{CHCl}_{3}\right)$, and dichloromethane $\left(\mathrm{CH}_{2} \mathrm{Cl}_{2}\right)$.

\section{Results and discussion}

The yield of isolated cellulose was found to be $51.23 \%$ of the dry sawdust of black poplar wood. Cellulose esters were obtained by acylation, using octanoyl chloride. The DS was controlled by the molar ratio of anhyroglucose units in cellulose/octanoyl chloride. The carbon contents, DS values, and yield percentages of octanoylated celluloses are given in Table 1.

Table 1. Acylation of cellulose with different concentrations of octanoyl chloride

\begin{tabular}{ccccc}
\hline Sample & $\begin{array}{c}\text { Octanoyl chloride } \\
\text { (Equiv) }\end{array}$ & C $(\%)$ & DS & $\begin{array}{c}\text { Yield } \\
(\%)\end{array}$ \\
\hline 1 & 2 & 59.29 & 1.13 & 56.36 \\
2 & 3 & 61.68 & 1.53 & 65.69 \\
3 & 4 & 63.07 & 1.83 & 72.69 \\
4 & 5 & 64.29 & 2.15 & 80.16 \\
5 & 6 & 64.82 & 2.31 & 83.90 \\
6 & 7 & 65.33 & 2.48 & 87.86 \\
7 & 8 & 65.72 & 2.62 & 91.13 \\
8 & 9 & 65.95 & 2.71 & 93.23 \\
\hline
\end{tabular}




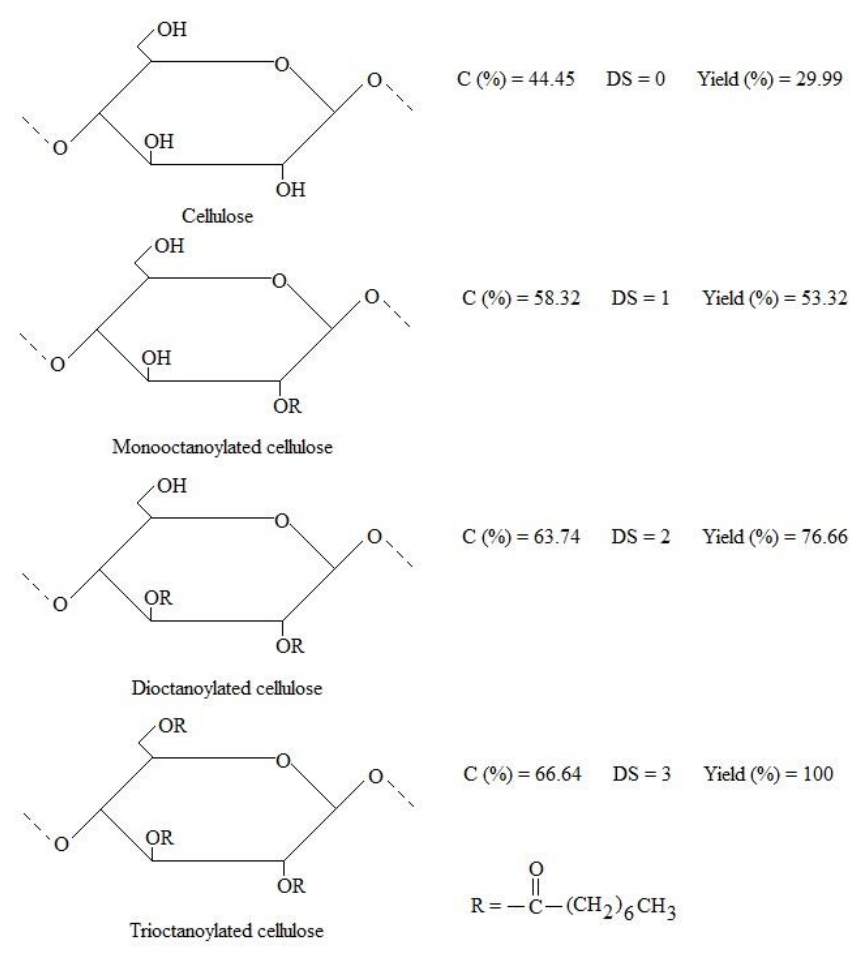

Figure 1. Octanoylation of Cellulose

The DS and yield varied from 1.13 to 2.71 and $56.36 \%$ to $93.23 \%$, respectively. Lowest DS (1.13) and yield (56.36\%) were obtained from sample 1 when the low molar ratio (1:2) of anhyroglucose unit/octanoyl chloride. The findings here exhibited that a progressive increase of molar ratio of octanoyl chloride and anhyroglucose unit raised the DS and yield percentage values of octanoylated celluloses. The cellulose esters with DS values lower than 1 would not be suitable to prepare polymer films (Antova et al., 2004). It was observed that octanoylated celluloses in this study met the required DS value for using in the production of biodegradable or environmentally degradable plastics.

The graphic in Figure 2 shows that DS values increased linearly from 1.13 to 2.15 for molar ratio varying from $1: 2$ to 1:5 (anhyroglucose unit/octanoyl chloride). After 2.15, the DS values constitute a shoulder until 2.71. Each anhyroglucose unit in the structure of cellulose contains three reactive hydroxyl groups at the C-2, C-3, and C-6 atoms (Fengel and Wegener, 1984; Krassig, 1993). OH groups in position C-6 and C-2 of anhyroglucose unit are favored for acylation to an equal degree over those in C-3. In fact, the octanoylation of cellulose reached never trisubstitution (DS=3) (Samaranayake and Glasser, 1993). Therefore, the findings here are compatible with the literature.

Solubility of octanoylated celluloses with different DS in various solutions is showed in Table 2 .
Table 2. Solubility of octanoylated celluloses with different DS

\begin{tabular}{ccccccc}
\hline Sample & DS & DMSO & DMF & THF & $\mathrm{CHCl}_{3}$ & $\mathrm{CH}_{2} \mathrm{Cl}_{2}$ \\
\hline 1 & 1.13 & + & + & 0 & - & - \\
2 & 1.53 & + & + & 0 & - & - \\
3 & 1.83 & + & + & + & 0 & 0 \\
4 & 2.15 & + & + & + & + & + \\
5 & 2.31 & + & + & + & + & + \\
6 & 2.48 & + & + & + & + & + \\
7 & 2.62 & + & + & + & + & + \\
8 & 2.71 & + & + & + & + & + \\
\hline +: soluble, o: swellable, -: insoluble. & & & &
\end{tabular}

Cellulose is by nature hydrophilic due to the $\mathrm{OH}$ groups in its molecular structure (Fengel and Wegener, 1984). The introduction of hydrophobic acyl groups into the polymeric structure of cellulose would be anticipated to alter its solubility. Such a change in solubility would essentially depend on the DS. Previous works have reported that all tested polysaccharides isolated from lignocellulosic materials esterified with acyl chlorides were soluble in pyridine and in dimethylsulfoxide (DMSO); however, those with low DS values were only partly soluble in tetrahydrofuran (THF), toluene, chloroform $\left(\mathrm{CHCl}_{3}\right)$, and dichloromethane $\left(\mathrm{CH}_{2} \mathrm{Cl}_{2}\right)$ (Rahn et al., 1996; Lepeniotis and Feuer, 1997; Sun et al., 1999; 2000). In this study, all cellulosic derivatives obtained by octanoylation solubilized in DMSO and DMF. Derivatives with low DS values of 1.13 and 1.53 partially solubilized in THF, and not solubilized in $\mathrm{CHCl}_{3}$ and $\mathrm{CH}_{2} \mathrm{Cl}_{2}$. Derivatives with DS value of 1.83 partially solubilized in $\mathrm{CHCl}_{3}$ and $\mathrm{CH}_{2} \mathrm{Cl}_{2}$. Other derivatives solubilized in THF, $\mathrm{CHCl}_{3}$ and $\mathrm{CH}_{2} \mathrm{Cl}_{2}$. These findings showed that the esterification of cellulose from black poplar sawdust using octanoylation improved hydrophobic capacity. 


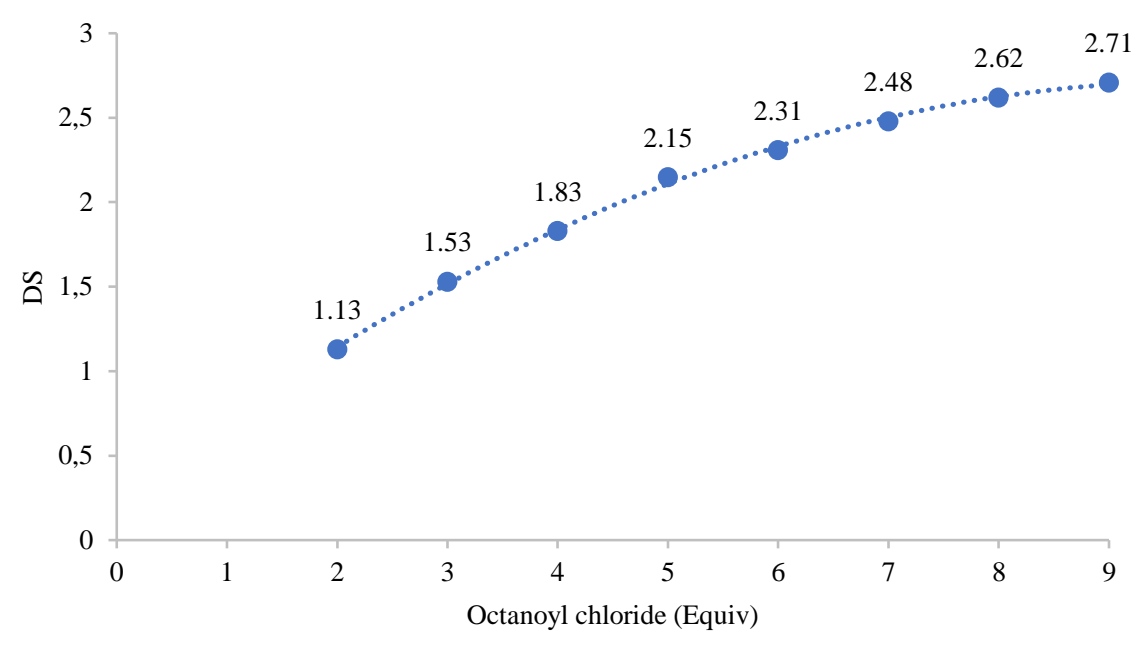

Figure 2. DS values of cellulose acylated using different concentrations of octanoyl chloride

\section{Conclusion}

Black poplar sawdust is available in large quantities as lignocellulosic waste produced by the forest industrial processes. For this reason, the practicability of black polar sawdust as an alternative raw material in the production of cellulose derivatives was investigated in this study. The isolated cellulose was esterified with different concentrations of octanoyl chloride. DS values of produced cellulose derivatives varied between 1.13 and 2.71. Percent yields were ranged from $56.36 \%$ and $93.23 \%$. Solubility analysis indicated that the esterification of cellulose improved hydrophobic capacity with increased DS values. The study showed that the produced cellulose derivatives are present in sufficient quantity to be used as raw material in the production of biodegradable and environmentally degradable plastics, resins, films, and coatings for use in some industrial areas such as the food and pharmaceutical industries.

\section{References}

Antova, G., Vasvasova, P., Zlatanov, M., 2004. Studies upon the synthesis of cellulose stearate under microwave heating. Carbohydr. Polym., 57: 131-134.

Arikan, E.B., Bilgen, H.D., 2019. Production of bioplastic from potato peel waste and investigation of its biodegradability. International Advanced Researches and Engineering Journal, 3(2): 93-97.

Civitarese, V., Acampora, A., Sperandio, G., Assirelli, A., Picchio, R., 2019. Production of wood pellets from poplar trees managed as coppices with Different harvesting cycles. Energies, 12(15): 2973.

Crepy, L., Chaveriat, L., Banoub, J., Martin, P., Joly, N., 2009. Synthesis of cellulose fatty esters as plastics-influence of the degree of substitution and the fatty chain length on mechanical properties. ChemSusChem, 2(2): 165-170.

Fengel, D., Wegener, G., 1984. Wood-Chemistry, Ultrastructure, Reaction, Walter de Gruyter, Berlin.

Gaudet, M., Jorge, V., Paolucci, I., Beritognolo, I., Scarascia Mugnozza, G., Sabatti, M., 2008. Genetic linkage maps of Populus nigra L. including AFLPs, SSRs, SNPs, and sex trait. Tree Genetics and Genomes, 4:25-36.
Heredia-Guerrero, J.A., Goldoni, L., Benítez, J.J., Davis, A., Ceseracciu, L., Cingolani, R., Bayer, I.S., Heinze, T., Koschella, A., Heredia, A., Athanassiou, A., 2017. Cellulosepolyhydroxylated fatty acid ester-based bioplastics with tuning properties: Acylation via a mixed anhydride system. Carbohydrate Polymers, 173: 312-320.

Joly, N., Granet, R., Krausz, P., 2003. Crosslinking of cellulose by olefin metathesis. Journal of Carbohydrate Chemistry, 22: 4755 .

Joly, N., Granet, R., Branland, P., Verneuil, B., Krausz, P., 2005. New methods for acylation of pure and sawdust-extracted cellulose by fatty acid derivatives - Thermal and mechanical analyses of cellulose-based plastic films. Journal of Applied Polymer Science, 97(3): 1266-1278.

Joly, N., Martin, P., Lienard, L., Rutot, D., Stassin, F., Granet, R., Krausz, J.P., Cavrot, J-P., 2006. Effect of degree of substitution on the mechanical and thermomechanical properties of lauroyl cellulose ester films. e-Polymers, 70: 1-9.

Kahraman, T., Kahraman, F. K., Karakaya, S., Karahan, A., Ünsal, G., Karatay, H., Toplu, F., 2011. Türkiye'de Karakavakta (Populus nigra L.) 1slah çalışmaları 'Fidanlık aşaması sonuçları'. T.C. Orman ve Su İşleri Bakanlığı Kavak ve Hızlı Gelişen Orman Ağaçları Araştırma Enstitüsü Müdürlüğü, Teknik Bülten No: 210, İzmit, Türkiye.

Krassig H.A., 1993. Cellulose: Structure Accessibility and Reactivity. Polymer Monographs, Vol. 11, Gordon and Breach Science Publishers, Amsterdam.

Kurschner, K., Hoffer, A., 1969. Ein neues verfahren zur bestimmung der zellulose in hölzern und zellstoffen. Technologie und Chemie der Papier- u. Zellstoff-Fabrikation, 26: 125-139.

Lange, J.P., 2007. Lignocellulose conversion: an introduction to chemistry, process and economics. Biofuels, Bioproducts and Biorefining, 1(1): 39-48.

Lepeniotis, S., Feuer, B.I., 1997. Synthesis of starch acetate: Statistical designed experiments to optimize the reaction conditions. Chemometrics and Intelligent Laboratory Systems, 36(2): 229-243.

Mark, H.F., Bikales, N.M., Overberger, C.G., Menges, G., 1985. Encyclopedia of Polymer Science and Engineering, Vol. 3: Cellular Materials to Composites. 2nd ed., Wiley-VCH, pp. 158-226.

McCormick, C.L., Callais, P.A., Hutchinson Jr, B.H., 1985. Solution studies of cellulose in lithium chloride and $\mathrm{N}, \mathrm{N}$ dimethylacetamide. Macromolecules, 18(12): 2394-2401.

Mediavilla, I., Esteban, L.S., Fernández, M.J., 2012. Optimisation of pelletisation conditions for poplar energy crop. Fuel Processing Technology, 104: 7-15. 
Monedero, E., Portero, H., Lapuerta, M., 2015. Pellet blends of poplar and pine sawdust: Effects of material composition, additive, moisture content and compression die on pellet quality. Fuel Processing Technology, 132: 15-23.

Moshood, T.D., Nawanir, G., Mahmud, F., Mohamad, F., Ahmad, M.H., Abdul Ghani, A., 2021. Expanding policy for biodegradable plastic products and market dynamics of biobased plastics: challenges and opportunities. Sustainability, 13(11): 6170.

Nosal, H., Moser, K., Warzała, M., Holzer, A., Stanczyk, D., Sabura, E., 2021. Selected Fatty Acids Esters as Potential PHB-V Bioplasticizers: Effect on Mechanical Properties of the Polymer. Journal of Polymers and the Environment, 29(1): 38-53.

Rahn, K., Diamantoglou, M., Klemm, D., Berghmans, H., Heinze, T., 1996. Homogeneous synthesis of cellulose ptoluenesulfonates in $\mathrm{N}, \mathrm{N}$-dimethylacetamide/LiCl solvent system. Die Angewandte Makromolekulare Chemie: Applied Macromolecular Chemistry and Physics, 238(1): 143-163.

Rathmacher, G., Niggemann, M., Kohnen, M., Ziegenhagen, B., Bialozyt, R., 2010. Short distance gene flow in Populus nigra L. accounts for small scale spatial genetic structures: Implications for in situ conservation measures. Conserv. Genet., 11: 13271338.

Samarasinghe, S., Easteal, A.J., Edmonds, N.R., 2007. Biodegradable plastic composites from corn gluten meal. Polymer International, 57(2): 359-364.

Samaranayake, G., Glasser, W.G., 1993. Cellulose derivatives with low DS. I. A novel acylation system. Carbohydr. Polym., 22(1): $1-7$.

Satge, C., Verneuil, B., Branland, P., Granet, R., Krausz, P., Rozier, J., Petit, C., 2002. Rapid homogeneous esterification of cellulose induced by microwave irradiation. Carbohydrate Polymers, 49: 373-376.
Satge, C., Verneuil, B., Branland, P., Krausz, P., 2004. Synthesis and properties of biodegradable plastic films obtained by microwave-assisted cellulose acylation in homogeneous phase. Comptes Rendus Chimie, 7: 135-142.

Sealey, J.E., Samaranayake, G., Todd, J.G., Glasser, W.G., 1996. Novel cellulose derivatives. IV. Preparation and thermal analysis of waxy esters of cellulose. Journal of Polymer Science Part B: Polymer Physics, 34(9): 1613-1620.

Sjöström, E., 1993. Wood Chemistry, Fundamentals and Applications, Second Edition, Acedemic Press, Inc., San Diego.

Sun, R.C., Fang, J.M., Tomkinson, J., Hill, C.A.S., 1999. Esterification of hemicelluloses from poplar chips in homogenous solution of N,N-dimethylformamide/Lithium chloride. Journal of Wood Chemistry and Technology, 19(4): 287-306.

Sun, R.C., Fang, J.M., Tomkinson, J., 2000. Characterization and esterification of hemicelluloses from rye straw. Journal Agricultural Food Chemistry, 48(4): 1247-1252.

Vaca-Garcia, C., Thiebaud, S., Borredon, M.E., Gozzelino, G., 1998. Cellulose esterification with fatty acids and acetic anhydride in lithium chloride/N,Ndimethylacetamide medium. Journal of the American Oil Chemists' Society, 75: 315-319.

Wang, X., Chen, Z., Yu, G., Yuan, X., 2018. Effects of poplar fibres as solid bridge on the physical characteristics of biomass briquette made from sawdust and bamboo powder. Wood Research, 63(1): 141-153.

Willberg-Keyrilainen, P., Ropponen, J., 2019. Evaluation of esterification routes for long chain cellulose esters. Heliyon, 5(11): $\mathrm{e} 02898$. 